音声言語医学 $59 ： 245-250,2018$

症例

\title{
0 歳代の早期に難聴が発見されることによる親の抱える問題
}

\author{
木村 聖子 ${ }^{1)}$ 能登谷晶子 ${ }^{3)}$ 諏訪 美幸 $^{1)}$ 山田 和宏 ${ }^{2)}$
}

要 約：新生巟聴覚スクリーニング等でわが子が難聴と診断された後の課題として, 親の障 害受容に対する支援が重要になる。今回，0歳代の早期に難聴が発見されたことによる親の抱 える問題について，3 例（親は 2 事例）の経過を示し, ST の立場からの親の支援について報 告する. 症例 1,2 はきょうだいである。 きょうだいともに難聴と判明したとき, 親は動摇し たが，早期からのSTによるサポートと，従来からわれわれが行ってきた患者会との交流，周 囲の援助も厚く, 親から子への積極的関わりが可能となり, 児の言語獲得は順調に進んだ。症 例 3 は前 2 例と同じ支援内容では当初障害受容が十分ではなく家庭での訓練が進まなかったが, 家庭で一定した関わりをもてるようになってから，児の理解語彙数は増加した，早期の難聴の 診断によって親は大きく動摇し, 既報告で指摘されていることが確認された。障害をもつ児を 受容する親への支援には, 多面的にかつきめ細かい指導と, ST は早期から家族関係の良否に も目を向ける必要があると考えた。

索引用語：難聴児，早期診断，早期療育，障害受容，親への支援

\section{Problems of Parents Arising from Discovery of Hearing Loss in 0-Year-Olds}

Kiyoko Kimura $^{1)}$, Masako Notoya ${ }^{3)}$, Miyuki Suwa ${ }^{1)}$ and Kazuhiro Yamada ${ }^{2)}$

\begin{abstract}
After a young infant is diagnosed with hearing loss in newborn hearing screening etc., support of parents in accepting their child's disability is important. In this study, we show the progress of 3 cases (involving 2 sets of parents) of parental problems caused by early detection of hearing loss at age 0 , and report on support of parents from the standpoint of speech-language-hearing therapists. Case 1 and case 2 are siblings. The parents were distressed when both siblings were found to have a hearing loss, but with support from a speech-language-hearing therapist from an early stage, interaction with the patient parent association, and solid support from family and friends, active involvement between the parents and their children became possible, and language acquisition has progressed smoothly. In Case 3, the same support as in the previous 2 cases initially was insufficient to enable acceptance of their child's disability, preventing progress in training carried out in the home. However, once home training reached a stable level of involvement,
\end{abstract}

恵寿総合病院言語療法課1), 同 耳鼻咽喉科 ${ }^{2)}$ ： = 926-8605 石川県七尾市富岡町 94 番地

京都学園大学健康医療学部言語聴覚学科 ${ }^{3)}$ : ₹615-8577 京都府京都市右京区山ノ内五反田町 18

${ }^{1)}$ Department of Speech Therapy, ${ }^{2}$ Department of Otolaryngology, Keiju Medical Center: 94 Tomioka-cho, Nanao, Ishikawa 9268605, Japan

${ }^{3}$ Department of Speech and Hearing Sciences and Disorders, Faculty of Health and Medical Sciences, Kyoto Gakuen University: 18 Yamanouchigotandacho, Ukyo-ku, Kyoto 615-8577, Japan 2017 年 7 月 21 日受稿 2017 年 10 月 5 日受理 
the volume of vocabulary understood by the child increased. In this case, the parents were greatly upset by the diagnosis of early hearing loss, and the issues indicated in previous reports were confirmed. These cases suggest that support to enable parents of young children with hearing disabilities to accept their situation requires multifaceted and detailed guidance as well as evaluation of the quality of family relationships by a speech-languagehearing therapist from an early stage.

Key words: hearing-impaired child, early diagnosis, early treatment, disability acceptance, support for parents

\section{はじめに}

近年, 新生児聴覚スクリーニング検査（newborn hearing screening, NHS) の普及, 補聴器や人工内耳 の技術的な発展，遺伝子診断の飛躍的な進歩により， 難聴の早期発見·診断・療育は進んでいる。森田ら ${ }^{11}$ は, 療育の課題として保護者が受ける精神的動摇への対応 方法および支援体制の確立に対する検討が重要である と報告している。われわれ言語聴覚士（以下，ST) は保護者に直接かかわる職種であるので，保護者への 支援の在り方について, 症例に合わせた具体的な対応 策を講じる必要があると考える.

これまでわれわれは, 聴覚障害乳幼児が紹介されて きたら, まず耳鼻咽喉科医師からの診断名の説明後に, 担当 ST が1)聴覚障害によって生じる言語聴覚障害に ついての説明, (2) NPO 難聴と共に歩む親子の会金沢 方式研究会（以下, 金沢方式研究会）に紹介して, 居 住地近くの会員を紹介する，(3)きょうだいともに難聴 であった場合には，同様の会員を紹介する，(4)乳幼児 期に金沢方式で訓練を受け，すでに中学生以上に達し ている患者を紹介する，等の支援体制を取っている.

今回は 3 事例 (うち 2 例はきょうだい)を提示し, きょ うだい例は，従来の体制で順調に訓練が進んだが，症 例 3 は，従来の体制では当初順調に支援が進まなかっ た。しかし, 父親による家庭内の環境調整の結果, 主 たる訓練者が交代した後に，ゆっくりではあるが言語 獲得が見られたので, 報告する.

\section{石川県の NHS 後のフォローアップ体制}

石川県では，聴覚障害児はNHS 後，精密検査機関 で聴覚障害の診断がついたら，療育方法を選択するよ うに精密検查実施機関の耳鼻咽喉科医師が指導してい る. 1つは, 特別支援学校（ろう学校）での教育で, もう 1 つは金沢方式 ${ }^{2)}$ と呼ばれる病院での訓練である. 特別支援学校での訓練を選択した場合には，学校は金 沢市内にあり，金沢市内から $100 \mathrm{~km}$ 以上離れている
能登地区から通学するのは困難なため, 母子だけが金 沢市内に生活して，そこから通学することになる例が 多い. 金沢方式は基本的には家庭で訓練を行う方法で, 病院には 1 回 $/ 2$ 週の頻度で通院し, そこで, 親は ST による個別指導を受ける。また, 1 回/週, 石川県社会 福祉会館で行われている難聴児の集団訓練（著者らの 一人が実施）に参加する.NHS が普及して, 生後数力 月から訓練が開始できるようになり，奥能登地区にあ る当院で，金沢方式による訓練希望者が増加する傾向 にある、

\section{症例}

症例 1（親 1）：小学 5 年生, 家族構成は祖父母, 両 親と妹の 6 人家族.

現病歴：NHS は pass していたが，母親が難聴を疑 い, $\mathrm{A}$ 病院耳鼻科を受診し， 7 カ月（0：7）のときに 難聴と診断された. 平均聴力レベルは $100 \mathrm{~dB}$ 以上. 0 : 8 から補聴器を両耳装用し訓練開始. $2: 7$ 時に左耳に 人工内耳埋め込み術（日本コクレア社製フリーダム） を B 病院で行い, 定期的にマッピングを受けている. $10 ： 9$ でフリーダムから N6に変更し, 平均装用闇值 は $30.0 \mathrm{~dB}$ である.

経過：支援は，難聴診断後すぐに母親の友人である ST から金沢方式を紹介され, 訓練を見学した後 $0: 8$ から金沢方式による訓練を開始し，患者会の紹介，地 域の同じ障害をもつ先輩の紹介を行った，同時に居住 地近くでの訓練を希望され当院に紹介となり，個別訓 練も開始した，母親は，「どうして」と「やっぱり」 の入り混じった複雑な心境と, 同時に「今できること をなんとかしないと」と次にする必要なことは何かに ついても言及していた。訓練は就学までは週に 1 回の 集団訓練, 2 週に 1 回, 個別訓練を実施し, 耳疾患に 罹患していないかについては当院耳鼻科でもフォロー された。語彙数は親が言語の学習状況を記したノート を基に評価している。ジェスチャー・聴覚読話・文字 おのおのの理解語の評価基準は, 対応する絵カード, 
または実物に相当するものの選択が，日を変えても 4 回以上再現できたとき，その記号のもつ意味が受信さ れたとし，1 語と数え，発信は，親がそれとわかる程 度で自発的に発したものを 1 語と数えている。本例の 場合，母親がノートは記載したが，語彙数は父親が集 計し夫婦での協力が見られた。本例の表出手段は 0 ： 11 から「バイバイ」と手話の表出が始まり，1：0か ら手話を併用しながらの音声言語が見られ，3:5頃 には音声言語のみとなった。理解語彙数は聴覚読話が $4: 6$ 時点で 3411 語, 就学時は 4866 語であった。 就 学時の WISC-III PIQ 114, 音声言語のみ使用で VIQ 120 , 小学 1 年時の読書力検査は小学 4 年レベル と言語獲得が良好であった。本例の会話明瞭度は 1 (よ くわかる)である。

\section{症例 2（親 1)：小学 2 年生}

現病歴：症例 1 のきょうだいであり, 症例 1 が 3 : 2 時に誕生した. NHSは要精密検査という結果であり, $0 ： 2$ のときに B 病院にて ABR 再検査を行い難聴と 診断された。平均聴力レベルは $100 \mathrm{~dB}$ 以上， $0: 3$ よ り両耳に補聴器装用し，金沢方式による訓練と当院で の個別訓練を開始した. $2: 5$ 時にB病院にて左耳に 人工内耳埋め込み術（N5）を受け，定期的にマッピ ングを受けている。平均装用䦨值は $27.5 \mathrm{~dB}$ である.

経過：母親は, 本例が生まれたときはショックが大 きい状態だったが，きょうだいともに難聴の子供をも つ地域の同じ境遇にある先輩を紹介したことにより， 前向きな気持ちになれたと述べていた。本例の表出手 段は $0: 8$ で「バンザイ」の手話表出から始まり, 0 ： 11 から手話を併用しながらの音声言語が見られ，3： 6 頃には音声言語のみとなった. 理解語彙数は聴覚読 話で $4: 6$ 時点が 2182 語, 就学時は 3657 語であった。 就学時の WISC-III VIQ 114 と平均を上回り, 読書力検査は小学 2 年 1 学 期レベルであった，会話明瞭度は 2 (ときどきわから ない語がある程度）である。症例 1 と比較すると, 理 解語彙数の伸びが緩やかであり，母親は症例 1,2 を 比較し焦りを感じていたが，きょうだい個々に応じた 言語指導を行い, 症例 1 の順調な言語獲得の状態から 今後の見通しについても説明することで，継続して家 庭での訓練に取り組むことができた。また，通院や家 事に损いては祖父母の協力も手厚かった。

症例 3 (親 2): 1 歳代, 家族構成は両親と本人の 3 人家族. 近くに父方の祖母が在住している.

現病歴: NHS は要精密検査という結果であり, C 病院にて ABR 再検査と ASSR を行い $0: 2$ で難聴と
診断され，月 2 回，検査と診察で通院した。平均聴力 レベルは $90 \mathrm{~dB}$ 以上であり, $0: 4$ から補聴器を両耳 装用し, 装用閾值は $45 \mathrm{~dB}$ 程度である。0:7 から金 沢方式による訓練を開始し, 当院での個別訓練も開始 した。

経過：週に 1 回の集団訓練, 2 週に 1 回個別訓練を 実施した，従来の患者支援体制に従い，金沢方式研究 会への紹介, 地域の同じ障害をもつ先輩を紹介し, 子 どもの言語獲得への聴覚の役割, 補聴器の役割, 声掛 けなどの言語刺激の重要性について, 家族への説明な ど，症例 $1 ， 2$ と同様の支援を行った，しかし，親の 障害受容, 特に母親が十分ではなく, 言語指導は 0 ： 7 から $1: 5$ まで親支援が中心となり, 父親と母親, 祖母, 個々に思いを聞くなど心理的サポートも実施し た。具体的な支援内容は表 1 に示した。訓練開始から 1 年近く親指導を中心に行ったが，母親はわが子の難 聴を受け止めることが困難であり，残念ながら母親は 子育てから離れた。父親は実家の祖母の援助を受ける という環境調整を行い, 1：6から日中は祖母が訓練 を担い, 夕方以降は父親が担当するという形態を取り 始めた。 そこで, 再度父親と祖母に対して, 声掛け, 聴覚読話の方法など，本児の喜ぶ遊びを用いながら言 語刺激の方法や課題の進め方について説明し, 語彙数 や学習状況を記すノート記載についても指導した，家 庭での訓練が母親から父親中心に変わったが, 祖母の 協力もあり，一定した関わりをもつことができるよう になった。

1 歳代の手話による理解の語彙数経過を症例 1,2 と合わせて図 1 に示した，症例 1,2 は右肩上がりに 語彙数が増加したが, 症例 3 は増加がなかった。 しか し, $1: 8$ 頃より目が合う, 動作模倣の増加が本児に 出現し, その後, 聴覚読話による理解でも語が増え, 現在では手話で 2 語文（例：マンマ欲しい）も出現し ている.

\section{考察}

0 歳代の早期に難聴が発見されることによる親の抱 える問題と言語獲得について 3 例（親 2 事例）の経過 を示した．親 1 は症例 1 の訓練開始時,「どうして」 と「やっぱり」の入り混じった複雑な心境であったが, 従来われわれが金沢方式研究会とともに取り組んでき たサポート体制である，先輩患者との交流などで児の 言語獲得が順調に進んだことから，親の気持ちも安定 した，症例 2 のときは，きょうだいともに難聴である ことに母親のショックは大きかったが, 症例 1 のとき 
表 1 症例 3 の親支援の内容

\begin{tabular}{|c|c|c|}
\hline 児の年齢 & 来院した家族 & 親支援の内容 \\
\hline 0 歳 7 力月 & $\begin{array}{l}\text { 両親 } \\
\text { 母親・祖母 } \\
\quad(\text { 父方 })\end{array}$ & $\begin{array}{l}\text { 母親は「今も半分は難聴だと信じられない」，父親は「しゃべれないのかな. 聴こえないことによっ } \\
\text { て情報が取り入れられなかったらうなるのか. 家で何をしたらよいのか知りたい」と父親から積 } \\
\text { 極的に質問あり. } \\
0 \text { 歳代に発達する音源探索反応について説明し，前言語期の指導を行った. }\end{array}$ \\
\hline 0 歳 8 力月 & 両親 & $\begin{array}{l}\text { 父親は身振りを使って児に示す. } \\
\text { コミュニケーションの相互に気づかせるために両親のやりとりをよく見せるようにするように指導. }\end{array}$ \\
\hline 0 歳 9 力月 & 両親 & $\begin{array}{l}\text { 音への反応についてや刺激の方法を説明すると, 父はその場で真似して行っていた. } \\
\text { 声掛けとともにジェスチャー (以下，G）を用いることを指導. }\end{array}$ \\
\hline 0 歳 10 力月 & 両親 & $\begin{array}{l}\text { 児とちょうだい-どうぞのやりとりができるようになっており, コミュニケーション関係の定着と物 } \\
\text { 品の機能操作の理解を増やしていくよう指導. }\end{array}$ \\
\hline 0 歳 11 力月 & 母親 & $\begin{array}{l}\text { 母親からできるようになったこと（G の模倣や事物同士のマッチング）の報告あり, 次の段階に進 } \\
\text { むこと（事物とカードのマッチング）や，声掛けとともにGを用いることを継続指導. }\end{array}$ \\
\hline 1 歳 & $\begin{array}{l}\text { 母親・祖母 } \\
\quad(\text { 父方 })\end{array}$ & $\begin{array}{l}\text { 言語期の訓練開始. 本人の興味あるものに合わせて声を掛け, Gをもっと使うように指導し，教え } \\
\text { ている } \mathrm{G} \text { を記載してきてもらった。祖母にも } \mathrm{G} \text { 使用の協力を依頼した. }\end{array}$ \\
\hline 1 歳 1 力月 & $\begin{array}{r}\text { 母親・祖父母 } \\
\quad(\text { 母方 })\end{array}$ & $\begin{array}{l}\text { 母親から行動発達は伝えられるが, } \mathrm{G} \text { の理解・表出語彙が増えた報告は無. 児が怒るようなことを } \\
\text { するようになり（物をすべて落とすなど，，怒りたくなくても怒ってしまうと母親が話す. } \\
\text { 行動発達から刺激できることを説明し，危ないこと以外，児が好きなことをできる場所を作れない } \\
\text { か提案した. }\end{array}$ \\
\hline 1 歳 2 力月 & 両親 & 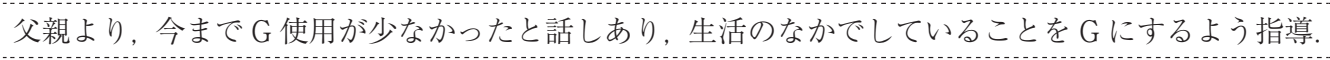 \\
\hline 1 歳 3 力月 & 母親 & $\begin{array}{l}\text { 母親より気持ちの落ち込みがある内容が聞かれ，児が } 2 \text { 週間でできるようになった変化を伝え，励 } \\
\text { ました。 }\end{array}$ \\
\hline 1 歳 4 力月 & 両親 & 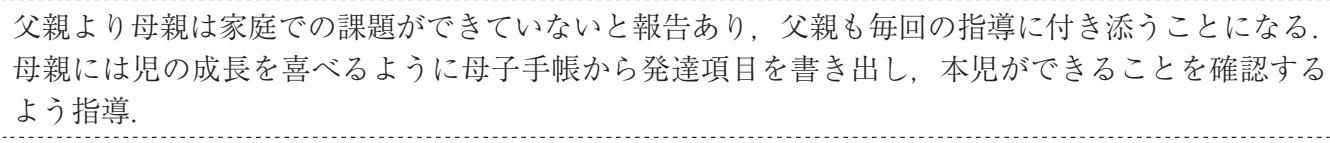 \\
\hline 1 歳 5 カ月 & 両親 & $\begin{array}{l}\text { 家族会の先輩宅を訪問し, } G \text { 刺激を意識して両親で行っていると報告あり。 } \\
\text { 場面ごとの声掛けのシナリオを書いてもらい, 同じ場面で同じ } G \text { を繰り返し使用し刺激することを } \\
\text { 指導. }\end{array}$ \\
\hline
\end{tabular}

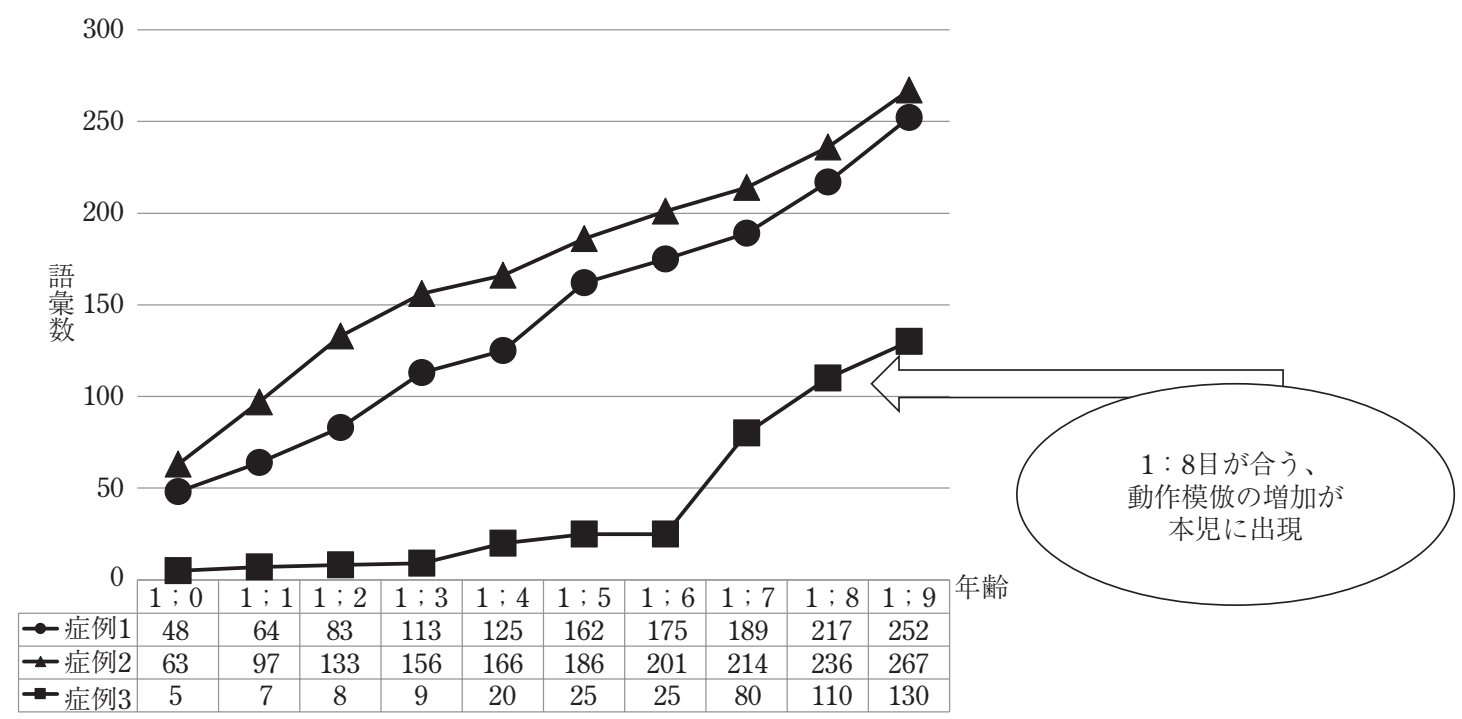

図 13 例の手話による理解の語彙数経過 
と同様の支援に加え同じ境遇（きょうだいともに難聴 の児をもつ)の先輩を ST が紹介し相談できたことと, 症例 1 の順調な成長が親の心理的な安定をもたらし た。このことにより, 症例 2 の言語獲得も就学時には 良好な結果となった。したがって, 症例 $1 ， 2$ は従来 からのサポート体制で児の言語獲得を促すことができ たと考えている.

一方, 親 2 は親 1 と同様の支援内容だけでは母親が 児の難聴を受容できず訓練が困難であり，約 1 年にわ たり家族指導を中心に行ったが，主たる訓練者は母親 から父親と祖母に交代した. 祖母が日中訓練を担当し, 夜は父親が担当するという，これまでわれわれが経験 したことのない形態となったが，訓練の主たる担当者 が交代してから，毎日安定して症例 3 に対応する時間 の確保ができたためか, 児のジェスチャーや手話の理 解が増加傾向を示し始めた（図 1).

この症例 3 の経過から，母親でなくてもそれに近い 人が安定して日中子どもに言語刺激をすることで，子 どものジェスチャー・手話の理解を増加させることが できることがわかった。したがって，養育者で，子ど もに直接言語刺激をする者の心理的安定が著しく重要 であることも，今回の症例を通して学んだ点である. われわれの親指導の進め方で，うまく行かなかった点 については，今後さらに検討していきたい. しかし， 症例 3 の父親による環境調整の結果, 児にとって安定 した言語習得環境を提供できることになった点につい ては, 訓練当初より, 父親も訓練に積極的になれない 母親にいつも付き添って外来通院し，われわれの指導 内容を理解していた結果ではないかとも推測してい る.

金塚ら ${ }^{3)}$ は，聴覚障害児をもつ親に対し，STがど のようにかかわっていくかについて, 初期は親の気持 ちに耳を傾け，親が子どもの障害をしっかり受け止め て，できるだけ早く療育に取り組むことができるよう にサポートすることが大切であると，述べている，聴 こえやことばなどの聴覚障害全般についての情報や聴 覚障害児を育てた親が集まる交流会などの場を提供し ていくことは，親が子どもの障害を理解し，今後の見 通しをもち，安定した状態で早期に療育を開始するう えで重要であるとしている。症例 1,2 の場合, 初期 から次にすることは何かと障害を受け止めることがで き，患者会との関わりから見通しをもてたこと，祖父 母の協力と父親のサポートもあり，母親を中心に早く 療育に取り組めた例と考える.

症例 3 は家庭環境, 特に夫婦関係において ST が早
期からその問題に気づく必要があったことを痛感した 例であった，原田ら ${ }^{4)}$ は家族の支援で大事なこととし て, 夫婦の会話を促し，祖父母の心配に答えることを 挙げている。 また，佐鹿 ${ }^{5)}$ は，親が障害のあるわが子 を受容していく過程での支援について，障害受容にか かわる要因 12 カテゴリー (1)障害の説明と理解の促 進，(2)障害と育児の重圧からの解放，(3)新たな夫婦関 係の発展，(4)身近な人の支え，(5)専門職からの支え， (6)育児方法と介護方法の蓄積, (7)育児と介護に向かう 力の源，8ライフサイクルの先を見越した準備，(9) どものもてる力の発揮，(10きょうだい児の自己実現， (11)親の生きる力と生活の充実, (12)生活の保障) を面接 から抽出し，危機的時期・状況を乗り越えていくとき の「複合的な力」となっていると報告している。症例 3 について，佐鹿が提示しているわが子の障害受容の どこに問題があったかは, 今回は症例 3 の母親から(3) 夫婦関倸のこと, (7)育児に向かう力の源, (11)生活の充 実，12)生活の保障などについて指導中に聴取していな いので，検討できない，しかし，今回の経験から，両 親の関係，生活力（収入など），それぞれの子育てに ついての考え方などについてもきめ細かい指導を行っ ていく場合には，情報源として必要になると考えてい る.

\section{ま と め}

0 歳代の早期に難聴が発見されることによる親の抱 える問題について，3 例（親は 2 事例）の経過と ST の立場からの親の支援について考察し, 以下の結論を 得た。

1. 早期の難聴の診断は親の心理面に影響し, 親の 心理面の動摇と, 難聴に対する理解, 受け止め方が子 どもの言語獲得に影響していることが推測された。

2。障害をもつ児を受容する親への支援には，ST は多面的にかつきめ細かい指導と早期から家族関係の 良否にも目を向ける必要があると考えた。

利益相反自己申告：申告すべきものなし．

謝辞 本稿をまとめるにあたり，情報提供にご協力いただき ましたNPO 法人難聴と共に歩む親子の会金沢方式研究会会員 の皆様に心より感謝申し上げます.

本論文の要旨は第 61 回日本音声言語医学会（2016 年 11 月, 横浜市)にて発表した。

\section{文献}

1）森田訓子, 伊藤茂彦, 山口 暁：新生児聴覚スクリーニン グの問題点と今後の課題一保護者へのアンケート調査によ 
る検討一. Audiology Japan, 47 : 49-55, 2004.

2）鈴木重忠, 能登谷晶子 : 聴覚障害児の言語指導一金沢方式 をかえりみて一。音声言語医学, 34：257-263, 1993.

3）金塚智恵子, 若島 睦：第 2 章 聴覚障害. 言語聴覚療法 臨床マニュアル 改訂第 3 版, 協同医書出版社, 東京, 86-87 頁, 2014.

4）原田浩美，能登谷晶子：聴力障害児をもつ親への支援プロ グラムの開発一親の自己効力感を高める支援一. 科学研究 費助成事業基盤研究（C) JSPS 科研費 JP25381328：3,
2017.

5）佐鹿孝子：親が障害のあるわが子を受容していく過程での 支援（第 4 報）：ライフサイクルを通した支援の指針。小 児保健研究，66 (6)：779-788，2007.

別刷請求先： =926-8605 石川県七尾市富岡町 94 番地 恵寿総合病院言語療法課 木村聖子 